This is the Author's Accepted Manuscript, draft pre-print, post peer-review version of the following article, which was published in Urban Studies. You can access the final version here http://usj.sagepub.com/content/early/2014/07/02/0042098014540346.abstract

\title{
Transnational migration and urban informality: Ethnicity in Buenos Aires' informal settlements
}

\author{
Tanja Bastia ${ }^{1}$ \\ University of Manchester
}

Contact details: Tanja Bastia, University of Manchester, 1.064 Arthur Lewis Building, Oxford Road, Manchester M13 9PL, UK. Email: Tanja.Bastia@Manchester.ac.uk

\begin{abstract}
Ethnicity is playing an increasingly important role in the ways in which informality is governed and regulated across cities in the global south. This raises concerns regarding the ensuing exclusion experienced by some groups of people living in informal settlements. In this paper I use the example of Buenos Aires, Argentina, to explore the extent to which ethnicity plays a role in the informal settlement. There is significant evidence that Argentina has gone through a process of de-ethnicisation, particularly at the national level. However, it is unclear whether this process is also evident at the level of the informal settlement. Drawing on a range of interviews, the paper finds that while grassroots organisations are de-ethnicising, the formal leadership of the informal settlement and to some extent also migrants reproduce ethnic divisions. The deethnicisation led by the state has therefore unequally percolated to the micro level.
\end{abstract}

Keywords: ethnicity; migration; cities; informality; exclusion; Buenos Aires.

\footnotetext{
${ }^{1}$ I would like to acknowledge the support of the British Academy for the Post-Doctoral Fellowship (PDF/2007/182) as well as a doctoral scholarship provided by the University of Wales Swansea for funding this research. A number of people read previous drafts and provided comments, for which I would like to thank Jorge Ginieniewicz, Nina Glick-Schiller, Michael Hebbert, Huraera Jabeen, Melanie Lombard, James Scorer, the international conference on Conflict, Fragmentation and Hope in the Neoliberal City: Urban Space in Latin America, Amsterdam, The Netherlands, 6-7 November 2008; the Centre for Latin American and Caribbean Studies at the University of Manchester; and anonymous Urban Studies referees for their useful and constructive comments. I would also like to thank Lucia Vera Groisman for stimulating discussions in Buenos Aires. All errors are obviously mine. The research would not have been possible without the participation of the interviewees, some of whom provided extensive contacts, practical support in often difficult contexts and opened their homes and personal experiences to me. I gratefully acknowledge their very kind participation in this research project.
} 


\section{INTRODUCTION}

Cities embody the potential for providing large numbers of people with basic services, such as clean water, health and education, as well as the space within which to learn to deal with 'difference', as Lefebvre argued (Mitchell, 2003; see also Datta, 2012a). Cities are also increasingly the sites where citizenship is determined and practiced (Holston and Appadurai 2000). However, since the early period of rapid urbanisation it has become apparent that not everyone benefits from what the city has to offer. Increased mobility both within and across national borders pose opportunities but also additional challenges to achieving equal rights to the city (Harvey, 2008; Koonings and Kruijt, 2007). Nowhere can this be more evident than in informal settlements, which have ceased to be a phase in urban development and became permanent features of cities in the global south (Datta, 2012a; McFarlane, 2008; Roy, 2011). Informal or squatter settlements are sites of multiple exclusions, both material and social (Davis 2006). Yet these are also increasingly heterogeneous, with differences often framed in terms of ethnicity. Moreover, there is also increasing evidence that ethnicity, or its local equivalent such as caste, plays an increasingly important role in the ways in which informal settlements are governed and regulated (AlSayyad and Roy 2006; Datta 2012b; Jha, Rao and Woolcock 2007).

It is well known that cities receive large numbers of migrants. However, despite the fact that south-south migration now comprises almost half of all cross-border movements (Ratha and Shaw, 2007), there has been comparatively little research on international migration to cities in the global south (Balbo and Marconi, 2005). Given that many cross-border newcomers are quite likely to find work or at least accommodation in informal neighbourhoods (see e.g. Landau and Monson 2010), there is a clear need for better understanding of the relationship between migration, informality and exclusion in cities in the global south. There are three scales of analysis that matter: the nation-state, the city and the informal settlement. The nation-state is critical for facilitating migrants' rights, but has already received a lot of attention. The role of the city is likewise very important, but was not taken into account during fieldwork and is currently being explored in a new project ${ }^{2}$. These two levels, the city and the nation, are often in tension, not least because they are ruled by different parties. This paper, however, focuses on the smallest of these scales, the informal settlement, given that this has thus far received least attention, particularly in its treatment of international migration. This paper approaches the relationship between migration and informality by examining ethnicity and how it is employed by three different groups of people in the informal settlement: transnational migrants, elected leaders (who are themselves internal migrants) and grassroots organisations.

It is clear that those who mediate between informal settlements and the city authorities play a critical role in representing the needs of their residents (Jha, Rao and Woolcock 2007). Their perception of who is deemed to have a legitimate right to the informal settlements is therefore critical. Buenos Aires provides a good base from which to explore the relationship between ethnicity, migration and informality. Outside of national and regional academic circles, most work to date acknowledges its history of European migration, particularly from Southern Europe, or its history of internal migration (e.g. Seekings 2012). ${ }^{3}$ Less well known is its continued role

\footnotetext{
${ }^{2}$ See http://informalpoliticsinthecity.wordpress.com/

${ }^{3}$ Some early transatlantic migrants lived in informal settlements e.g. in villa 31 , which was known as 'barrio inmigrantes' because most of its inhabitants were Italian (Keeling 1996). However, the growth of informal settlements is associated with internal migration and urbanisation. The paper therefore focuses on this history of
} 
as a regional centre of attraction for migrants from its neighbouring countries: Bolivia, Paraguay, and Chile but also Peru. This regional migration has recently been 'blamed' for the growth of informal settlements in the City of Buenos Aires (Perasso 2009; declaration by City Governor Mauricio Macri in Clarín 2010).

In addition, some have argued that the post-crisis period brought a de-ethnicisation of everyday life (Grimson 2006). However, the data in this paper suggests that this has only partly been achieved. While at the national and grass-roots levels there is evidence that ethnicity is slowly becoming less relevant, formal representatives of the informal settlements continue to draw legitimacy on the basis of ethnicity. Migrants themselves at least in part also reproduce these divisions, as will be shown below.

The analysis draws on interviews with Bolivian migrants recorded in various informal settlements in the City and Gran Buenos Aires in 2003 (19 interviews) and in 2008 (17 interviews). These are complemented with 3 interviews with grassroots organisations and elected representatives in one informal settlement, which I will call Villa Palude ${ }^{4}$, conducted in 2008. For most of the fieldwork I lived with migrants in two informal settlements in Buenos Aires. Therefore some observations are drawn from fieldwork notes. The paper also draws on statistical data obtained from the Instituto Nacional de Estadistica y Censos - INDEC and the City of Buenos Aires' Unidad de Gestión de Intervención Social (UGIS), Coordinación General de Asistencia Comunitaria (Social Intervention Unit). Given the time the fieldwork took place, the paper does not take into account more recent developments, such as the invasion of the Parque Indoamericano in December 2010, but speaks of the context leading up to it.

\section{INFORMALITY, ETHNICITY AND MIGRATION}

During the industrial revolution in England as well as in twentieth century Latin American, large sections of the population who have been drawn to the city as 'labour' have never fully benefited from 'urban' life (Engels, 1987; Gilbert, 1998; Portes, 1989). While for Lefebvre (1996) the city provides the means through which people can learn from each other and overcome their differences, the shaping of some groups as 'different' often prevents all inhabitants of a city to fully benefit from it, be it the Irish in eighteenth century Manchester (Engels, 1987), nordestinos in Saõ Paulo (Caldeira, 2000), or Zimbabweans in South African informal settlements (Landau, 2011). This 'difference' is often framed on the basis of ethnic identity.

Taking on board Çaglar and Glick Schiller's calls for more attention on how migrants re-scale cities (2011) and Smith's work on transnational urbanism (2000), this paper focuses on the role that ethnicity plays in the informal settlement. I do this through an examination of migration, both in terms of the ways in which transnational migrants experience ethnic-based discrimination and the ways in which ethnicity plays a role in their everyday lives; for example, how they use social networks and the role this plays in their access to jobs and housing. The current formal leadership also has a history of migration, albeit internal. Yet, there is little identification between their own experience of internal migration and those of international migrants.

internal migration and the international migration from neighbouring countries - for a review of the history of migration in Argentina see Devoto (2003).

${ }^{4}$ Villa Palude is a fictional name of an informal settlement, used to preserve the anonymity of my interviewees. 
I therefore use migration as a way of examining ethnicity, but these are not equated. Whilst there is some overlap between migration status and ethnic differentiation, I am more interested in exploring how ethnic divisions are produced in the context of informality, following Barth's understanding of ethnicity, discussed below.

The empirical data suggests that ethnicity plays a key role in the ways in which migrants are socially excluded. It shows that the historical exclusion experienced by internal migrants, who are today part of the informal settlement leadership, is being reproduced by these leaders towards international migrants. Foreign-born status therefore compounds the already significant exclusion that informal dwellers have experienced throughout the twentieth century. To understand this process of compounded exclusion, we need to take into account three levels of analysis: the state - where decisions are made in relation to national economic and migration policies; the city - which mediates national policies and is responsible for the provision of housing and services for urban dwellers; and the informal settlement - whose formal organisms (in this case, the Junta Vecinal), represents the needs and interests of those living in informal settlements. In this paper I review some of the already available material with regards to the first two and provide new evidence for the third, i.e. the informal settlement.

Acknowledging the worsening economic and social conditions experienced in Latin American cities since the 1990s (see e.g. Rodgers 2009), the approach adopted in this paper also values the multiple ways that people continue to make a living and sometimes achieve fulfilment in their projects of social mobility (Perlman 2010). Such an approach therefore aims to promote a more holistic view of the ways in which people embrace their everyday adversities and make the most of them, transcending the essentially dualistic manner in which Latin American cities have been understood historically. I therefore highlight interviewees' agency while at the same time also acknowledge the fact that cities 'integrate both positive and negative tendencies' (Rodgers et al. 2012).

Second, while significantly distinct, I wish to draw out parallels between informality and illegality, particularly as this has emerged as a significant topic in discussions in the informal settlement. As others have argued, informality in land titling, or squatting, has been "more usefully understood as unregulated activities in a context where similar activities are regulated" (AlSayyad and Roy 2006:8, citing Portes et al. 1989). AlSayyad and Roy's work in particular argues that informality is an expression of the power of the state to establish the state of exception (2006; see also Datta, 2012b).

While clearly referring to different processes - land titling and movement across space - the state intervenes in a similar manner with its desire to regulate movements across its national borders. As with land informality, differing opinions exist as to how these movements should be understood. Some see the movement across national borders without the required documentation as criminal and therefore see these migrants as 'illegal'. Others understand this movement as merely breaking administrative rules, and therefore speak of 'undocumented' or 'irregular' migration (see de Genova 2005 for a full discussion). There seems to be an overlap between the two positions in that people engage in some activities - seeking work in a country other than the one of their birth, or build houses on land that they do now own - and by doing this break property or migration legislation, which places them in a situation of 'irregularity' or informality vis-à-vis the state. 
However, undocumented migrants and informal squatters, hold different relationships with the state. Cross-border migrants are non-citizens, while (national) squatters are citizens. The state has a responsibility to protect fundamental rights of all but national citizens are often granted greater entitlements. In the case study under discussion, however, specific groups of foreign nationals, i.e. those who are nationals of a country member or affiliated to MERCOSUR, enjoy the right to live and work in Argentina, which puts them in a very similar position with Argentinean nationals who also live in informal settlements.

Third, ethnicity often plays an important part in determining who belongs to the nation and who is therefore granted legal citizenship. However, there are differing conceptions of ethnicity at different scales. The nation-state has been associated historically with an ethnically homogenous nation, with minorities and those who do not conform to the ethnic norm, excluded (Wimmer, 2002). However, ethnicity is also active in everyday life, outside of nationalistic discourses of belonging and exclusion. While the Chicago School of urban sociology associated ethnicities with nationalities, I draw on the distinction made by Barth (1969), which is more closely associated with the everyday construction of people's ethnic identity, which may, or may not, be associated with a specific nation-state.

For Barth, ethnicity is produced and reproduced in everyday construction of people's identities, through constant negotiations of group boundaries. His primary interest was the persistence of theses boundaries despite the fact that many people cross them. At the macro level the construction of ethnic identity discourses is also relevant. However, here I draw on Barth's notion of ethnicity as everyday practice and identification with a particular territory as this often has material consequences for the people involved. At the nation-state level, the process of deethnicisation represents an explicit attempt to overcome inequalities associated with migration status, by granting greater legitimacy to migrants in terms of the rights and resources they have access to whilst in Argentina. At the city and informal settlement level, on the other hand, there are competing understandings of who is perceived to be a 'legitimate citizen' or 'legitimate informal settlement dweller'. Many of the issues discussed so far can relate to groups that are 'different' but hold a similar position in the socio-economic hierarchy in a particular context. However, who is seen to have a 'legitimate claim' on a particular space or action becomes imperative when we take into account different positions of authority.

Before moving on I would like to briefly discuss the concept of legitimacy. Legitimacy is most commonly used in political science, where it denotes the accrual of political legitimacy i.e. the extent to which political institutions are able to harness a moral position that gives them legitimacy (Beetham, 1991). While this perspective is relevant for the material presented in this paper, it is also important to highlight its reverse, i.e. how those in power and tasked to represent a particular group of people, identify a legitimate support base. This perspective is much closer to Hannah Arendt's notion of rights, which underpins the moral distinction between those who are seen as having a claim to rights and those who are not (see also Fraser, 2005). This is a problem of both representation i.e. who is represented by the political authorities, and recognition, i.e. who is considered a legitimate member of a particular community. As I will show, while the city - here embodied by city authorities and urban elites - has historically discriminated against its informal settlements, at times violently evicting them from the city boundaries, the formal representatives of informal settlements likewise discriminate against foreign born citizens, not deeming them having sufficient legitimacy as 'shanty town dwellers', 
similar to the concept of bona fide resident in Alexandra township in Johannesburg, South Africa (Noor 2011).

\section{MIGRATION AND VILLAS MISERIA in BUENOS AIRES}

To better contextualise the relationship between migration and informality, this section draws on secondary data to show how the city has historically excluded informal settlements and the changing nature of migration in Buenos Aires' informal settlements: first internal and more recently, international. This is important. Some of the formal representatives of informal settlements today draw on their own history of exclusion to legitimise their own position in the informal settlement. At the same time, they do not deem the presence of international migrants in the informal settlement as legitimate. This is despite the fact that international migrants' reasons for living in the informal settlement are very similar to those of internal migrants forty years ago.

When informal settlements started emerging in Buenos Aires, during the 1930s, they were largely tolerated by the national Peronist government because it drew support from its inhabitants (Svampa, 2005). However, the local population stigmatised internal migrants because of their rural background, including racial stereotyping on the basis of their darker skin and indigenous ancestry (Ratier, 1971-1975 and 1985). This was a process of racialisation of the recently arrived internal migrants that bears some similarities with the racialised ethnicisation process witnessed during the 1990s towards international migrants, particularly Bolivians (see Grimson, 2006).

Government's lenient policies towards informal settlements changed radically with the military regimes $^{5}$ that came into power in 1976 and initiated a deep process of socio-economic restructuration (Svampa, 2005), relocating economic activity, outside of the Buenos Aires city belt marked by the Avenida General Paz (Rofman, 1985). This was a deliberate attempt to 'cleanse the city' and eliminate any possible threat of resistance by distancing workers from the political centre. All informal settlements were banned from the city in 1977.

Forced evictions with the aim of eradicating shanty towns from the City of Buenos Aires, which had had experienced a 111.7 growth in just six years preceding the coup, became a key element of national policy (Auyero, 1999:55). An estimated 208,783 people were affected (Blaustein, 2006). The new policies of industry relocation 'aimed to transform the CBA from a disorganized and menacing industrial hub, where less affluent workers and slum-dwellers crowded in the low neighbourhoods, into a site where a "hygienic, pleasant community life" would prosper' (Libertun de Duren 2008:130, italics in original).

City authorities did not see the people who were forcefully removed as deserving to live in Buenos Aires, as the then Director of the Comisión Municipal de la Vivienda made clear in a speech delivered in 1980:

'Not anyone can live in the City of Buenos Aires. An effective effort should be made to improve the health and hygienic conditions. In fact, living in Buenos Aires is not for

\footnotetext{
5 There had already been earlier attempts at eradicating informal settlements, first under the government of President Arturo Ilia (1963-66) and then the 1967 Plan for eradications (law 17,605) under General Juan Carlos Onanía (19661970). However, these were not very successful (see Keelings for a brief review). Following the coup in 1976 the military regimes passed the Law of Eradication in 1977 banning all villas from the Federal Capital (Silva and Schuurman 1989).
} 
everybody, but only for those who deserve it, for those who accept the regulations of a pleasant and efficient community life. We have to have a better city for the better people.' (cited in Libertun de Duren 2008: 129)

The city's rejection of informal settlements was put into practice through the physical relocation of those living in informal settlements to outside the city of Buenos Aires and the population living in informal settlements decreased from 3.4 percent in 1970 to 1.3 percent by the end of the decade (INDEC, 1980 Census data).

With the return of democracy in 1983, industrial investment was brought back into the capital, and informal settlement population experienced 42 percent growth between 1980 and 1991 and then a further 105 percent growth between 1991 and 2001. The rate of increase slowed during the last inter-censal period but the proportion of people living in informal settlements nevertheless increased from 3.9 percent to 5.7 percent of the total population of the City of Buenos Aires between 2001 and 2010 (Census 2010, provisional results).

Table One: Population living in villas, City of Buenos Aires, 1960-2010

\begin{tabular}{|l|r|r|r|r|r|r||}
\hline \multicolumn{8}{|c|}{ POPULATION LIVING IN VILLAS, CITY OF BUENOS AIRES, 1960-2010 } \\
\hline & 1960 & 1970 & 1980 & 1991 & 2001 & 2010 \\
\hline Total population & $2,966,634$ & $2,972,453$ & $2,922,829$ & $2,965,403$ & $2,776,138$ & $2,890,151$ \\
\hline Total population in villas & 34,430 & 101,000 & 37,040 & 52,608 & 107,422 & $163,587^{6}$ \\
\hline Percent living in villas & $1.2 \%$ & $3.4 \%$ & $1.3 \%$ & $1.8 \%$ & $3.9 \%$ & $5.7 \%$ \\
\hline \hline
\end{tabular}

Source: DGEyC (2008) and Census data (INDEC)

At the same time, the policies implemented during the 1990s aggravated all socio-economic indices of wellbeing, from income distribution, real incomes, to unemployment and underemployment, which Auyero termed 'hyperunemployment' even before the 2001 crisis (1999:49). This was a radical departure to the stability and cohesion of previous historic periods when the national-populist governments were in place (Grimson and Kessler, 2005; Svampa, 2005).

The 1990s was also a period of increased international migration towards the City of Buenos Aires, particularly from neighbouring countries such as Paraguay, Bolivia and Chile. During this time the government increasingly blamed social ills, such as increasing unemployment, raising crime rates and a cholera outbreak, on migrants from neighbouring countries but did little to reform migration legislation. This led to the increasing ethnicisation of everyday social relations as racialised ethnicity was increasingly used to demarcate specific groups of people (Grimson, 2006) as the testimonies in the next section illustrate.

Argentina met the new millennium with an explosive economic and political crisis, widespread looting and mass social mobilisation (North and Huber, 2004). Unemployment and underemployment became rampant. But the crisis itself generated an enormous amount of new political organisation, including by middle class people, who had not previously been politically active (Grimson and Kessler, 2005). The economic and structural changes in previous decades,

\footnotetext{
${ }^{6}$ Provisional result.
} 
which led to increased informalisation, had weakened and fragmented traditional forms of political participation, such as workers' unions. The crisis also generated new forms of social protest (Manzano, 2009), including the taking over of closed factories, the temporary closure of main transport routes - piquetes, and temporary takeover of public space (see also Auyero, 2006; Rodgers et al. 2012).

While the 1990s saw an increase in the ethnicisation of everyday life, Grimson (2006) argues that ethnic demarcation decreased during the post-crisis period, given that migrants integrated themselves in neighbourhood based social movements, which organised around class-based issues. There is also evidence of de-ethnicisation taking place at the national level, with the passing of very progressive migration policies (Bastia and vom Hau 2014). The Ley de Migraciones 25,871 put forward by the Kirchner (Néstor) government (2003-7) was approved in 2003 and implemented the following year. It guarantees the principle of no discrimination, the protection of migrants' rights, including access to social services independently of migration status and the prohibition of automatic deportations. The government also ratified the International Convention of the Rights of All Migrant Workers and Members of their Families in February 2007, the only 'receiving' state to have done so. A legalisation campaign benefitted over half a million migrants by regularising their situation (Cerrutti, 2009). These were major improvements, which made a significant difference to migrants' everyday lives. They show that Argentina was promoting de-ethnicisation through its national policies. They also show that ethnicity and migration status were playing decreasing importance in the distribution of entitlements to human rights, basic services and the right to stay and work in Argentina, at least in principle. This strategy placed Argentina at the forefront of progressive migration legislation globally. However, as I argue below, the process of de-ethnicisation of everyday life has been promoted by the state and through some parts of the post-2001 social movements. At the meso levels of analysis, such as the formal representatives of informal settlements, ethnicity continues to be used to demarcate 'others', particularly migrants, with the purpose of delegitimizing their claims to space. Buenos Aires consolidated itself as the main destination for migrants from neighbouring countries (Cerrutti, 2009; DNP, 2010). In fact, data from the most recent regularisation programme, which began in 2006, indicates that half of all Peruvians, a third of all Bolivians and a fifth of all Paraguayans arrived within the City of Buenos Aires, where they are concentrated in just four neighbourhoods in the South and South-West of the City (Cerutti 2009). This is the old industrial centres, where most informal settlements are located and where fieldwork took place. City representatives have 'blamed' migration from neighbouring countries for the growth of informal settlements. There is some evidence that foreign born people are over-represented in informal settlements. For example we know that 24 percent of all MERCOSUR migrants live in villas de emergencia (DNP, 2010). On a more local level, a recent census of Villa 31 and Villa 31 bis, which had increased by 116 percent between 2001 and 2009, showed that over half of its inhabitants are foreign born (DGEyC, 2009) - compared to an average of 11 percent of foreign born in the City of Buenos Aires. However, there is no citywide data to determine to what extent migration from foreign countries drives the growth of informal settlements in the city as a whole. Any such assessment would also need to take into account the contribution that migrants make to the city itself (Çaglar and Glick Schiller, 2011). Having shown that the city has historically excluded informal settlements and that these have been associated with migration since their inception, the next section will focus on one informal settlement in particular with the aim of analysing whether this process of de-ethnicisation, which began at the nation-state level, can also be seen in the informal settlement. 


\section{ETHNICITY IN THE INFORMAL SETTLEMENT}

The section will begin by presenting migrants' experiences of their everyday lives in informal settlements, particularly in relation to ethnicity, both in terms of their experiences of ethnicbased discrimination as well as how they mobilise ethnicity in their everyday lives. The following section will present the views of the formal representatives of informal settlements. The final section will discuss some of the social movements that have been active in this area since 2001.

\section{Migrants' experiences of ethnicisation}

Bolivian migration is primarily a labour migration. Throughout the 1990s the peso parity with the US dollar provided the greatest incentive for seeking work in Argentina. Many of the migrants who migrated during this period found accommodation and sometimes also work in informal settlements. The reasons are multiple, and range from cheaper rents, social network or wanting to be closer to other Bolivians.

Natalia, for example, described she felt lonely when renting a flat in the neighbourhood of Lugano because there were no other Bolivians. This was a particularly difficult time for her, because she had just had a baby:

'I mean, there weren't any Bolivians there. [We had] Argentineans on both sides. [...] I didn't go out. Of course, I'd say hi but nothing else. $\quad\left(22^{\text {nd }}\right.$ March 2003)

Eventually she convinced her partner to move to Villa Palude, an informal settlement in the South of the City of Buenos Aires. For her the villa is also a place of kinship, friendship and warmth, suggesting that shared ethnicity is important for some migrants who choose to live in the informal settlement.

Their preference might be surprising, given that many migrants link informal settlements with danger but also with more intense discrimination, as described by Carlos, a bus driver:

'It is here in the villas, in the poorest areas, among those who have the least, that Argentineans discriminate against us the most, the villeros. I met Argentineans at work and they are good. They are not like this. Those I work with are not like this. No, they treat you like one of them. But the people who live around here, they call you boliviano [Bolivian], they insult you ( $3^{\text {rd }}$ June 2008).

Most migrants interviewed in 2003 mentioned discrimination based on origin as an everyday occurrence. This is also supported by newspaper articles that regularly reported violence towards Bolivians. During this period of ethnicisation, migration status, and lack of it to a large extent mediated migrants' use of space in the City of Buenos Aires. This has been less the case since the introduction of the new migration legislation in 2004 and the legalisation programme Patria Grande in 2006. During the second period of fieldwork, in 2008, there were markedly fewer instances of migrants who reported fear, ethnic-based discrimination or limiting their own mobility to only certain parts of the city.

Migrants actively resisted the imposed illegality preceding the new migration legislation. Sometimes they organised around common interests, such as music or sports, to provide each 
other with support and companionship. Juan, for example, explained that: 'He was the president of our football association. One day he said: 'There are so many people from our town, why don't we form our own football league?' And we did. It was going well. We had many teams, almost 40 teams' (3rd June 2008).

The football leagues were particularly important because they brought together a high number of football teams over the weekend in the Parque Indoamericano. Most teams were organised on the basis of the players' town of origin. Others set up associations providing support for newcomers, again on the basis of their region or town of origin. Some of these aimed at providing general support, such as emergency accommodation and health care for newly arrived migrants. Most of these initiatives were set up by migrant men, using their ethnicity and town of origin as the basis for organising football teams. By doing this, they also reproduced ethnic differentiation.

Those migrants who had higher levels of education or jobs outside of the 'ethnic community' were often called upon to mediate between migrants and Argentinean society. Juan, for example, who had a university degree and worked as a social worker, was once called upon to help a neighbour deal with Argentinean institutions. Referring to some of his neighbours, he said:

"When they face an office of an institution, they don't have the words to express themselves. The other day came a girl. She said her three year old fell off the roof and broke his head, poor kid. They walked days because they wouldn't give them his body because the police was suspicious. They were asking: how did he fall? Who is he? Do you have any witnesses? [...] So they came to look for me and we went everywhere, to the morgue, the police commissary, and it was like two in the morning, but we went to get the body, at that time, so one does these things as well, and coincidentally, the girl was also from [same town of origin in Bolivia] (3rd June 2008).

While many migrants rely on ethnic-based social networks for everyday companionship, help and support, many are also aware that ethnic-based organisations run the risk of perpetuating distances between migrants and Argentineans as well as between different groups of migrants. Because of this, many aim to transcend them. Juan, for example, is active in ethnic-based organisations but also collaborates with an Argentinean social worker to eradicate labour exploitation in informal garment workshops (many of which are run by Bolivians). Jesús, who works in a (formal) textile factory, opposes the idea of Bolivian organisations because he feels that they would increase discrimination towards Bolivians. His view was that there are laws against discrimination in Argentina so there is no real need for Bolivians to form separate organisations. There are tensions, therefore, in terms of migrants' attitudes towards the process of ethnicisation. Most speak of the consequences of the ethnicisation in terms of the discrimination they experience, but there is no agreement as to the strategy that they should employ to overcome it. Some participate in Bolivian organisations while others see them as detrimental. Some have also taken an active role in local politics by participating in local election campaigns or joining grassroots organisations.

The formal elected leadership of the informal settlement is particularly important, given that it mediates between those living in a villa and the city authorities. This includes negotiating upgrading schemes. They also witness (informal) land transactions and have the power to decide who has use rights of a particular piece of land. The next section will explore the ways in which the elected leadership of the informal settlement constructs legitimacy i.e. who they deem to have a legitimate claim on informal space. 


\section{Villa leadership and the construction of the legitimate slum dweller}

Villa Palude is today one of the largest shanty towns located in the Southern part of the City of Buenos Aires. It is formally represented by the President and his committee, the Junta Vecinal, who are democratically elected every three years by the villa residents (house owners and tenants). The Junta Vecinal formally represents villa residents in all dealings with the City authorities or other formal entities.

According to the President, there are three main moments in the history of the villa: the land invasion by internal migrants from Rioja, Cordoba and other regions in Argentina; the (partial) eradication by military regimes; return of democracy and increased migration from neighbouring countries.

'The military came in $1969,70,71^{7}$. They left it all empty, destroyed everything with machines. They beat us out with sticks. They killed, threw people in the countryside and left 47 families. Of those 47 families there were two cooperatives [...] set up so that the military couldn't throw you out in that way. Then came the invasion of the foreigners.' (President of Junta Vecinal, $9^{\text {th }}$ June 2008)

As will be shown, the current leadership uses this history of resistance as the basis on which to grant legitimacy, together with a discourse on need, from which foreign-born citizens are often excluded. This is despite the fact that according to the Junta Vecinal, over half of the population is Bolivian (55-60 percent) and up to a quarter Paraguayan. The census made available by UGIS puts the figures at a much lower 30 percent Bolivians and 14 percent Paraguayans (UGIS 2007) ${ }^{8}$.

In his account, foreign-born residents are categorised with emotive language, (e.g. 'invasion'), or as not particularly needy, living in Villa Palude to set up (informal) garment workshops or build houses to rent: 'The Bolivians are the only ones who still buy now because prices are high. But why are Bolivians the only ones who buy? Because they build houses upwards, to set up workshops, to let out rooms [implying Bolivans profited from building large houses in the informal settlement i.e. much larger than needed]' (President of Junta Vecinal, $9^{\text {th }}$ June 2008).

A few months preceding the interview in 2008, grassroots organisations had invaded adjacent land to call city authorities to account on housing conditions. When asked to describe the purpose of the invasion, the President explained: '[The purpose of the invasion was] to usurp [steal] the land. [...] We have been fighting for those flats [upgrading scheme] for 15 years for the villa, not for those who have arrived recently. They are mischievous.'

He describes how some of those who participated built three storey houses in just a few months, highlighting that they are not 'needy': 'The toma [occupation] was in December, October. They are people from outside, who came. Many Bolivians, Paraguayans, came. Relatives of those who

\footnotetext{
${ }^{7}$ These dates are not consistent with the actual eradication policies (see footnote 3 above) but are the dates given by the interviewee.

${ }^{8}$ Unfortunately the census data was only made available a year after the interview so I could not probe the President about the discrepancy but it is likely that he is counting children born in Argentina of Bolivian parents as Bolivian citizens, despite the fact that they have automatic right to Argentinean citizenship.
} 
have been living here for a long time [...] There is one who built a three storey house. He built a three storey house to rent' (President of Junta Vecinal, $9^{\text {th }}$ June 2008). Studies report that similar strategies are quite common in informal settlements in other parts of the world (e.g. Datta 2012b:61). What is different in this case is that the legitimacy of this action is diminished because those who employ it are foreign citizens. That is, the President does not acknowledge that this action is in fact exactly the same as the one carried out by his parents when they first occupied the land that is Villa Palude. The language used points to the creation of a 'legitimate shanty town dweller', a law-abiding (Argentinean) citizen, who has no other choice but to live in the shanty town, because he cannot afford to live anywhere else.

As was argued in the previous section, many migrants indeed 'choose' to live in a villa. However, this choice is constrained by the nature of their social networks, the debts they may have entered into through or prior to migration as well as economic and social conditions at origin. Moreover, having low education and/or being visibly 'Bolivian', means that economic opportunities in Buenos Aires are severely constrained, often to niche occupations such street trading or informal garment work. The leadership, on the other hand, portray migrants as wanting to live in the villa to take advantage of subsidies. By doing this, they also fuel ethnic stereotypes, particularly in relation to Bolivians.

While stating that they represent anyone who lives in the villa, irrespective of nationality, ownership or migrant status, the language used by the Junta Vecinal suggests that they see themselves as representing those fitting the category of 'legitimate shanty town dweller' (Noor 2011). For them, this category is limited to those who have a longstanding affiliation with the territory they inhabit as well as 'real' need for living in shanty towns, as defined by the Junta Vecinal, which does not recognise the multiple reasons why people might live in these areas. To a great extent this discourse excludes non-citizens and those who lack the historical continuity with territory.

\section{The piqueteros}

The crisis in 2001 also spurred the growth of myriad different grass-roots organisations that do political work, often in opposition to the local political leadership and the state. The popular soup kitchens are one such organisation. They were set up as a direct response to the political and economic crisis of 2001 and are closely linked with the piqueteros movement (Auyero, 2006). One of the comedores was set up in 2002 with the aim of providing poor children in Villa Palude with a daily hot meal and afternoon milk. In contrast to the Junta Vecinal Presidents' depiction of migrants as being relatively wealthy, most children who come to the comedor are migrants' children, some of whom come barefoot.

However, their work is not limited to service provision. They are directly involved with political mobilising around urban issues, such as the approval of state benefits for the unemployed or local villa needs, such as the provision of water services or fixing the faulty electricity lines. While they recognise that they have a membership representing different nationalities, they do not discriminate against non-citizens and place everyone on the same level when it comes to claiming rights.

For example, one leader, who is Argentinean, described her long history in one of the villas of the City of Buenos Aires, from where she was then moved to the province and only after 1984 
her family returned to the City of Buenos Aires (to another villa). In 1987 she came to Villa Palude and stayed: 'When I came here, they threw me out with heavy machinery three times, but the third time I stayed. They didn't come back. This was all fields, full of water, dirt and grass. Then, bit by bit, it became what it is today' (Leader of grassroots organisation, $28^{\text {th }}$ May 2008).

While tracing her history to the period of eradications and also being one of the first ones to return and claim a plot after the transition to democracy, at no point during the interview she makes claims that this would give her greater legitimacy to the villa of today. In fact, she highlights that her organisation is representative of a much broader spectrum of residents.

'We had many compañeros (comrades) who rented their accommodation, many migrants, Bolivians, Paraguayans, Peruvians, who came from their country and didn't have a place to rent. Or, if they rented, they were paying too much rent. Some had 4 or 5 children and were renting a small room of 4 by 4 [metres] with a shared bathroom where they would have to wait for an hour so that the other person with all the family would finish using the bathroom. So in our view having a place to live was a major problem for our compañeros.'

In stark contrast with the formal leadership of Villa Palude, members of this grass-roots organisation construct their legitimacy in terms of the contemporary needs of all villa residents, whether they may be Argentinean citizens or born in another country. This suggests that in contrast to the formal villa leadership, grass-roots organisations are in a better position to integrate foreign-born members of the informal settlement and represent their interests, because they allocate legitimacy on the basis of class, as opposed to ethnicity or historic association with a territory.

\section{CONCLUSION}

This paper explored the relationship between ethnicity, informality and migration by first reviewing the growth and expulsion of informal settlements from Buenos Aires and then focusing more closely on more recent experiences of informality. I use in-depth semi-structured interviews with a group of Bolivian migrants living in informal settlements in Buenos Aires and complemented them with interviews with members of the Junta Vecinal and grass-roots organisations in one particular neighbourhood. This approach facilitates an in-depth exploration of the history of informal settlements and one informal neighbourhood in particular, to understand the micropolitics of everyday social relations. The material illustrated the extent to which different groups of people draw and allocate legitimacy on the basis of territorial affiliation and therefore, to some extent, ethnic differentiation.

The first part of the paper showed the importance of the national scale of analysis. In particular, with the return of democracy informal settlements began to grow, which coincided with greater international migration to Buenos Aires during the 1980s, followed by a period of ethnicisation of everyday life during the 1990s.

The 2001 crisis brought a total collapse of the economic and political system, but also new forms of social organisations, which encouraged the de-ethnicisation of everyday life at the national level. However, by drawing on data collected from migrants, grassroots organisations and elected informal settlement representatives, this paper showed that the process of deethnicisation of everyday life in Argentina has only partially been achieved. In particular, elected 
leaders continue to frame social relations on the basis of ethnicity, drawing on their own long term association with the territory to justify a superior right to the informal settlement, while devaluing those who have arrived more recently. The ways in which these exclusionary identities of (territorial) belonging continue to shape the politics of representation has repercussions for who is seen to belong to the city and who is seen to have the right to claim rights to the city. Grassroots organisations, on the other hand, are encouraging de-ethnicisation of everyday social relations by framing their constituents on the basis of need and class, as opposed to place of birth or ethnicity. Finally, migrants, who to some extent reproduce ethnic differences by drawing on place of origin-based social networks for support and companionship, are also actively involved in grassroots organisations and therefore contribute to breaking down ethnic barriers.

By combining the analysis of how informal areas have been viewed from the city and state point of view, with an analysis of differentiations within informality (AlSayyad and Roy 2004), it has therefore been possible to come to a better understanding of the heterogeneity that exists in some informal settlements. While migration has been a constant in the history of informal settlements, some formal leaders of informal settlements use the foreign-born status of recent migrants as a basis to disenfranchise parts, sometimes the majority parts, of the population they are meant to represent.

These findings therefore support AlSayyad and Roy's (2004) thesis that ethnicity plays an important role in the governance of informal settlements. However, it cautions that this is only partly the case given that there are strong drivers at the state and the grassroots levels that are actively working to de-ethnicise everyday social relations. This suggests that these two levels provide greatest potential for the building of more inclusive cities.

Argentina is clearly an exception to the global trend of increasing the barriers to the migration of low income migrants. As governments in middle-income developing countries continue to provide few if any institutional frameworks to protect migrants' rights, while nevertheless having economies that are benefiting from their cheap and flexible labour, transnational, South-South regional migration will continue to grow. Many of these migrants will continue to find accommodation, jobs and companionship in informal neighbourhoods. As has been argued in this paper and continues to be witnessed with acts of horrific violence against migrants in different parts of the world, the place of migrants in cities of the global south requires urgent research as well as political action to ensure the protection of migrants' human rights and to create more inclusive cities. As this article has shown, in-situ, longitudinal analysis and a historical approach become critical for understanding the ways in which past histories of migration inform current migrations and the everyday politics of belonging and exclusion.

\section{REFERENCES}

AlSayyad, N. and A. Roy (2004) 'Urban informality: crossing borders', in: A. Roy and N. AlSayyad (eds) Urban informality: transnational perspectives from the Middle East, Latin America and South Asia, Lexington Books: Lanham and Oxford, pp.1-6

AlSayyad, N. and A. Roy (2006) 'Medieval modernity: on citizenship and urbanism in a global era', Space and Polity, 10(1): 1-20

Arendt, H. (2004) Origins of Totalitarianism. New York: Schocken books. 
Auyero, J. (1999) “This is a lot like the Bronx, isn't it?” Lived Experiences of Marginality in an Argentine Slum, International Journal of Urban and Regional Research 23(1), pp. 45-69.

Auyero, J. (2006) Protest in Contemporary Argentina: A Contentious Repertoire in the Making, in: P. Fernández-Kelly and J. Shefner (2006) Out of the Shadows: Political Action and the Informal Economy in Latin America. Pennsylvania: Pennsylvania State University Press, pp. 165-193.

Balbo, M. and G. Marconi (2005) Governing International Migration in the City of the South. Global Migration Perspectives 38. Geneva: Global Commission on International Migration.

Barth, Fredrick (1969) 'Introduction' in F. Barth (ed.) Ethnic Groups and Boundaries: the Social Organisation of Culture Difference, Boston: Little, Brown and Co.

Bastia, T. and vom Hau, M. (2014) 'Migration, Race and Nationhood in Argentina', Journal of Ethnic and Migration Studies, 40(3) pp.475-492.

Beetham, D. (1991) The Legitimation of Power. Basingstoke: Palgrave Macmillan.

Blaustein, E. (2006) Prohibido vivir aquí: la erradicación de las villas durante la dictadura. Buenos Aires: Cuadernos de Causa Popular.

Çaglar, A. and N. Glick-Schiller (2011) 'Introduction: Migrants and cities', in: N. Glick-Schiller and A. Çaglar, A. Locating Migration: Rescaling Cities and Migrants, Cornell: Cornell University Press, pp.1-19

Caldeira, T. P. R. (2000) City of Walls: Crime, Segregation and Citizenship in São Paulo. Berkeley: University of California Press.

Cerrutti, M. (2009) Diagnóstico de las poblaciones de inmigrantes en la Argentina. Serie de documentos de la Dirección Nacional de Población, numero 2, marzo 2009, Buenos Aires: Dirección Nacional de Población.

Clarín (2010) Macri habló de 'inmigración descontrolada' y recibió acusaciones de xenófobo. Clarín $10^{\text {th }}$ December, Buenos Aires.

Datta, A. (2012a) Mongrel City: Cosmopolitan Neighbourliness in a Delhi Squatter Settlement. Antipode 44(3), pp. 745-763.

Datta, A. (2012b) The Illegal City: Space, Law and Gender in a Delhi Squatter Settlement, Farnham: Ashgate.

Davis, M. (2006) Planet of Slums, Verso, London and New York

De Genova, N. (2005) Working the Boundaries: Race, Space and Illegality in Mexican Chicago, Duke University press

Devoto, F. J. (2003) Historia de la inmigración en la Argentina. Buenos Aires, Editorial Sudamericana.

DGEyC (2009) Censo de hogares y población, villas 31 y 31 bis. Gobierno de la Ciudad de Buenos Aires, Buenos Aires: Dirección General de Estadística y Censos. 
DNP - Dirección Nacional de Población (2010) Encuesta a inmigrantes en la Argentina 20082009. Serie de documentos de la Dirección Nacional de Población, numero 4, mayo 2010, Buenos Aires: Dirección Nacional de Población.

Engels, F. (1987) The Conditions of the Working Class in England, London: Penguin.

Fraser, N. (2005) 'Reframing Justice in a Globalising World', New Left Review, 36, pp. 69-88.

Gilbert, A. (1998) The Latin American City, London: Latin American Bureau.

Grimson, A. (2006) Nuevas xenofobias, nuevas políticas étnicas en la Argentina, in: A. Grimson and E. Jelin (eds) Migraciones regionales hacia la Argentina: diferencia, desigualdad y derechos, Buenos Aires: Prometeo.

Grimson, A. And G. Kessler (2005) On Argentina and the Southern Cone: Neoliberalism and National Imaginations. London: Routledge.

Harvey, D. (2008) Right to the City. New Left Review. 53 (September and October), pp. 23-40.

Holston, J. and A. Appadurai (2000) 'Introduction: cities and citizenship', in J. Holston (Ed.) (1999) Cities and Citizenship, Duke University Press, Durham and London

Jha, S., V. Rao and M. Woolcock (2007) 'Governance in the Gullies: Democratic Responsiveness and Leadership in Delhi's Slums', World Development, 35(2): 230-246

Keeling, D. J. (1996) Buenos Aires: Global Dreams, Local Crises, Wiley and Sons, Chichester.

Koonings, K. and D. Kruijt (2007) Fractured Cities, Second Class Citizenship and Urban Violence, in: K. Koonings and D. Kruijt (eds) Fractured Cities: Social Exclusion, Urban Violence and Contested Spaces in Latin America, London: Zed Books.

Landau, L. (Ed.) (2011) Exorcising the Demons Within: Xenophobia, Violence and Statecraft in Contemporary South Africa. Johannesburg: Wits University Press.

Landau, L. and T. Monson (2010) Immigration and Subterranean Sovereignty in South African Cities, in: A. Clunan and H. A. Trinkunas (eds) (2010) Ungoverned Spaces: Alternatives to State Authority in an Era of Softened Sovereignty, Stanford: Stanford University Press.

Lefebvre, H. (1996) Right to the City, in: Writings on Cities, translated by E. Kofman and E. Lebas. Oxford: Blackwell.

Libertun de Duren, N. (2008) Intertwining National and Urban Policies: National Development Strategies and Municipal Tactics in Greater Buenos Aires, Political Power and Social Theory 19, pp. 119-157.

Manzano, V. (2009) "Piquetes" y acción estatal en Argentina: Un análisis etnográfico de la configuración de procesos políticos, in: M. Grimberg, M.I. Fernández Álvarez and M. Carvalho Rosa (eds) Estado y movimientos sociales: estudios etnográficos en Argentina y Brasil, Buenos Aires: Editorial Antropofagia, pp. 15-36.

McFarlane, C. (2008) Sanitation in Mumbai's Informal Settlements: State, 'Slum', and Infrastructure. Environment and Planning A 40(1), pp. 88-107.

Mitchell, D. (2003) The Right to the City: Social Justice and the Fight for Public Space. London: Guildford Press. 
Municipalidad de la Ciudad de Buenos Aires (1991) La pobalción residente en villas en la ciudad de Buenos Aires. Su magnitud, localización y características. Transformaciones en el periodo 1960-1991, Dirección de estadística y censos, Serie Metodológica no.8, Buenos Aires

Noor, N. (2011) Xenophobia's Local Genesis: Historical Construction of Insiders and the Politics of Exclusion in Alexandra Township, in: L. Landau (Ed.) Exorcising the Demons Within: Xenophobia, Violence and Statecraft in Contemporary South Africa. Johannesburg: Wits University Press.

North, P. and U. Huber (2004) Alternative Spaces of the "Argentinazo" Antipode 36(5), pp. $963-$ 984.

Perasso, V. (2009) El "boom" de las villas miseria. $B B C$ Mundo. 18 June, http://www.bbc.co.uk/mundo/economia/2009/06/090616_pulso_vivienda_argentina_mes. shtml last accessed 24th January 2014.

Perlman, J. (2010) Favela: Four Decades of Living on the Edge in Rio de Janeiro. Oxford: Oxford University Press.

Portes, A. (1989) Latin American urbanization during the years of the crisis. Latin American Research Review 24(3), pp. 7-44.

Ratha, D. and W. Shaw (2007) South-South Migration and Remittances. Washington: World Bank.

Ratier, H. (1971-1975) El cabecita negra. Buenos Aires: Centro Editor de América Latina.

Ratier, H. (1985) Villeros y villas miseria. Buenos Aires: Centro Editor de América Latina.

Rodgers, D. (2009) Slum Wars of 21st Century: gangs, mano dura, and the new urban geography of conflict in Central America, Development and Change, 40(5), pp. 949-976.

Rodgers, D., J. Beall and R. Kanbur (2012) 'Re-thinking the Latin American City', in: D. Rodgers, J. Beall and R. Kanbur (eds) Latin American Urban Development into the $21^{\text {st }}$ Century: Towards a Renewed Perspective on the City. Basingstoke: Palgrave Macmillan.

Rofman, A. (1985) Argentina: a Mature Urbanisation Pattern, Cities, February, pp.47-54.

Roy, A. (2011) Slumdog Cities: Rethinking Subaltern Urbanism, International Journal of Regional and Urban Research, 35(2), pp. 223-238.

Seekings, J. (2012) 'Latin American Cities', introduction to virtual special issue, International Journal of Urban and Regional Research, http://www.ijurr.org/details/news/2339881/Virtual-Issue-on-Latin-American-Cities.html last accessed 24th January 2014.

Smith, M.P. (2000) Transnational Urbanism: Locating Globalisation. Oxford: Blackwell.

Silva, J. and F. J. Schuurman (1989) Neighbourhood associations in Buenos Aires: contradictions within contradictions, in F. J. Schuurman and T. Van Naerssen (eds) Urban Social Movements in the Third World, New York: Routledge.

Svampa, M. (2005) La Sociedad Excluyente. Buenos Aires: Taurus. 
Wimmer, A. (2002) Nationalist Exclusion and Ethnic Conflict: Shadows of Modernity, Cambridge: Cambridge University Press. 